\title{
효과적인 개발협력 파트너십에 관한 포럼 결과
}

효과적인 개발협력 파트너쉽에 관한 포럼이 $\mathrm{OECD}$ 회원국 및 중, 러, 사우디, 태국, 브라질, 남아공 등 14 개 여타 공여국, 국제기구(UNDP, $\mathrm{WB}, \mathrm{IMF})$ 대표들이 참석한 가운데 2005.2.1-2간 $\mathrm{OECD}$ 본부 에서 개최된 바, 주요 내용은 다음과 같음

\section{1. 주요 내용}

· $\mathrm{OECD}$ 와 신흥공여국간의 파트너쉽을 강화하기 위해 정기적 협의회를 개최키로 합의

· $\mathrm{OECD}$ 비회원국의 $\mathrm{ODA}$ 통계를 DAC에 자발적으로 제공키로 합의

· 원조효과 증진을 위해 수원국내에서 공여국간 조정 및 원조정책, 원조관리체제에 관한 정보 공유 합의

· 브라질은 $\mathrm{ODA}$ 의 증대가 어려움을 감안, 혁신적 재원조달방안으로 금융거래세, 무기판매세, $\mathrm{IMF}$ 의 특별인출권, 국제금융제도(IFF), 이민자 송금, 신용카드세 등에 대한 검토를 제의하고, 브라질, 칠 레, 프랑스, 스페인의 공동제안이라고 설명한 바, 이에 대해 미국이 강력히 반대함.

· 상기 내용을 포함하여 16 개항으로 구성된 의장성명 채택

\section{2. 포럼 개요}

· 금번 포럼에는 $\mathrm{OECD}$ 회원국 및 중국, 러시아, 사우디, 쿠웨이트, 태국, 말레이시아, 대만, 브라질, 칠레, 인도, 남아공, 이스라엘, 리비아, 튀니지 등 14 개 신흥공여국의 원조정책 담당 고위관리, $\mathrm{UNDP}, \mathrm{WB}, \mathrm{IMF}$ 등 국제기구 대표들이 참석함

- DAC 회원국과 여타 공여국간의 파트너쉽에 관한 회의는 1997년 멕시코에서 개최된 이래 8년 만에 개최 
· 금번 포럼은 DAC와 UNDP 공동주관하에 개최되고, DAC 의장 및 UNDP 총재보(개발정책국장 겸 임)가 공동의장으로 회의를 진행함

. 영국, 일본 정부가 포럼 개최를 위한 재정을 지원함

\section{3. 천년개발목표(MDG)의 도전}

- 대부분의 참석자들은 금년도 G8 정상회의 및 $\mathrm{MDG}$ 중간점검을 위한 $\mathrm{UN}$ 정상회의 개최 예정 등 개 발을 위해 중요한 한해라는 점을 언급하면서 $\mathrm{MDG}$ 달성을 위해 $\mathrm{DAC}$ 회원국과 신흥공여국간의 공 조 필요성을 강조하였음

\section{4. 경험공유 및 공조방안}

- 참석자들은 $\mathrm{DAC}$ 을 통해 지난 45년간 축적해 온 개발원조정책에 관한 지식 및 경험의 공유 필요성, 수원국내에서 다수 공여국간의 공조협력의 필요성, 남남협력 및 3각협력의 중요성을 강조함

- 신흥공여국들은 자국의 원조정책 및 원조현황을 개괄적으로 설명함

- 브라질은 빈곤감소목표 달성을 위해서는 ODA 외에도 매년 추가로 500 억불의 자금이 필요하며, 혁 신적 재원조달방안을 논의하기 위해 칠레, 스페인, 프랑스와 공동으로 UN 사무총장의 지지를 받아 뉴욕에서 50 여개국의 고위지도자가 참석하는 회의를 주도하였고, 지금까지 111 개국의 지지를 받았 다고 소개하였음

- 재원조달방안의 내용으로 금융거래세, 무기판매세, IMF의 특별인출권, 국제금융제도(IFF), 이민 자 송금, 신용카드세 등이 있다고 소개하고 이에 대한 검토를 제의하였음

- 이에 대해 미국대표는 미국 정부가 동 방안에 대하여 정책적으로 반대 의사를 분명히 표명하였 고, 이번 회의에서 논의하기에 적절하지 않다는 점을 지적하면서, 실제로 합의가 가능한 사항을 토대로 논의를 진행시켜 나가자고 하여 이에 대하여는 더 이상 논의가 되지 못하였음

\section{5. 효과적인 개발협력을 위한 파트너쉽}

· 참석자들은 효과적인 개발협력 파트너쉽을 강화하기 위해 $\mathrm{OECD}$ 회원국과 신흥공여국간의 정보교 류 및 통계공유, MDG 달성을 위해 북-남-남의 3각 협력의 적극 추진에 합의하였으며, 이번과 같 은 포럼을 정기적으로 개최하는데 합의하였음

- 또한 DAC 회원국의 개발원조에 관한 peer review시 신흥공여국들이 옵서버로 참여하는 방안을 검토하기로 하였음

- 개발을 위한 정책일관성 관련, 네덜란드, 스웨덴 등 일부국가에서는 내각차원의 합의를 통해 적극 추진하고 있는 반면, 캐나다 등 여타 $\mathrm{OECD}$ 회원국에서는 정책일관성문제를 전정부적으로 추진하 
는데 많은 어려움을 겪고 있다고 함.

- 우리 대표는 한국이 수원국에서 공여국으로 발전하는데 성공한 몇 안되는 나라중의 하나라고 말하 고, 한국이 외국의 원조를 받아 경제발전에 효과적으로 활용한 것은 강력한 정부가 ownership을 가지고 경제발전을 주도적으로 추진하였고, 잘살고자 하는 국민들의 강력한 의지가 결합되었기 때 문이라고 설명함

- 아울러 우리나라의 원조현황에 대해 소개하면서 우리나라의 무상원조는 수원국의 ownership을 존중하기 위하여 철저하게 수원국의 수요를 바탕으로 사업계획을 수립, 집행하고 있다고 설명함

\section{6. 관찰 및 평가}

· 최근 신흥공여국이 확대됨에 따라 수원국내에서 원조효과 증진을 위해서는 $\mathrm{OECD}$ 회원국과 신흥공 여국간의 조화 및 조정이 필요하다는 인식하에 금번 포럼이 개최된 바, 신흥공여국들이 고위급 대 표단을 파견하고 회의에 적극 참여함에 따라 소기의 성과를 거둔 것으로 평가됨

- $\mathrm{OECD}$ 회원국들은 신흥공여국들의 원조현황 파악을 목적으로 정보 및 통계 확보 체제를 수립하고, 앞으로 신흥공여국들이 그간 $\mathrm{DAC}$ 에서 제정된 원조규범을 준수하도록 유도하는데 중점을 두고 있 는 것으로 평가되는 바, 이는 앞으로 신흥공여국들의 자발적 협조 여부에 달려 있다고 보임 